\title{
THE DETERMINATION OF OLEIC ACID CONTENTS IN SUNFLOWER GENOTYPES
}

Yalcin KAYA, Trakya University Engineering Faculty, Genetic and Bioengineering Dept, 22100 Edirne, Turkey, yalcinkaya22@gmail.com (coresponding author)

Caglar COLAK, Trakya University Engineering Faculty, Genetic and Bioengineering Dept, 22100 Edirne, Turkey

Veli PEKCAN, Trakya Agricultural Research Institute, PO Box: 16, 22100 Edirne, Turkey

Mehmet Ibrahim YILMAZ, Trakya Agricultural Research Institute, PO Box: 16, 22100 Edirne, Turkey

Goksel EVCI, Trakya Agricultural Research Institute, PO Box: 16, 22100 Edirne, Turkey

\begin{abstract}
High oleic sunflower is new trend both in Turkey and also in the world due to that it present healthy vegetable oil and also higher standing ability for frying. Higher oleic acid also affects from environment especially nigh temperatures during the grain filling period but genetic contribution is also important. High oleic acid content comes from Pervenent mutation in sunflower and it controlling Ol genes. However, because of being a seed trait which is determining after harvest, it is so difficult and unnecessary works (waiting even low oleic ones until seed treshing, etc) to select high oleic sunflower genetic materials. Therefore, selection utilization of molecular markers for determining of higher oleic types help breeders a lot to select accurately high oleic ones and also reduce costs both workers, isolation material, etc... The study covers determining of higher oleic type sunflower genetic materials developed in National Sunflower Hybrid Breeding Project conducted by Trakya Agricultural Research Institute. To screen of high oleic acid genotypes, around 400 sunflower F2 and F3 individuals obtained from crosses between high oleic acid and low oleic acid lines were used in TUBITAK (The Scientific and Technological Research Council of Turkey) Project 1003-1140971. Fatty acids of sunflower genotypes were determined by Agilent 6850 Gas Chromatography in Trakya University Lab. Based on the study results, oleic acid contents of sunflower genotypes were changed between 21.9-91.8 \%, linoleic acid contents of them between 1.1-66.5\%, palmitic acid contents of them were between 3.4-8.0\% and stearic acid contents of genotypes were changed between 1.1-9.7\%. The higher oleic types were selected based on the study results for further generations.
\end{abstract}

Keywords: sunflower, oleic acid, quality, hybrid breeding

\section{INTRODUCTION}

Sunflower is one of the major oil crops in the world and mostly consuming as vegetable oil in frying, cooking or margarine. Normal sunflower oil (as called linoleic type) fatty acid composition is saturated acids $11 \%$ (stearic, palmitic), and unsaturated ones as oleic 20\% and linoleic acid 69\% (Baydar and Erbas, 2005; Lacombe et al., 2004). However, due to its high oxidative stability, higher stability in the frying process and exposure to high temperatures then more appropriate for frying and beneficial to health, mid (60-70\%) or higher (over 80\%) oleic type sunflower oil increase its importance year by year in the world. Oleic type sunflower production reached over $50 \%$ in Spain and France, almost $100 \%$ in US, but it was just started recently in Turkey and some Eastern European countries too (Kaya et al., 2008, 2015; Kaya 2016). Oleic type sunflower oil commonly uses especially fast food and snack sector currently and will be demanded more and more in other sectors in the world. It is also so suitable for biodiesel due to higher oxidative stability and also higher flash points, etc. (Vannozzi, 2006). Due to this healthy vegetable oil use trend especially in frying, higher oleic varieties will be enlarged frequently soon both in Turkey and also in the world (Kaya et al., 2008, 2015; Kaya 2016).

High oleic sunflower is firstly discovered in Russia and obtained by treating the seed of VNIMK 8931 by Soldatov utilizing from chemical mutations with 0.5\% DMS solution in Pervenent sunflower populations (Soldatov, 1976; Demurin and Borisenko, 2011). Oleic acid content is determined by Ol genes exhibiting dominant mode of inheritance with the nonadditive gene action and in addition to genetic factors it is also influenced highly by environmental factors (mainly night temperatures during grain filling period) (Fick, 1984; Urie, 1984; Andrich et al., 1992; Osorio et al., 1995; Demurin and Škorić, 1996; Fernández et al., 1999; Pacureanu-Joita et al., 1999, 2005; Demurin et al.,2000; Lacombe et al., 2000, 2002, 2004; Izquierdo et al., 2006; Joksimović et al., 2006; Škorić et al., 2007; Izquierdo and Aguirrezába, 2008; Velasco et al., 2008; Bervillé et al., 2009; Evci et al., 2009; Fernandez-Martinez et al., 2009; Lacombe et al., 2009; Kaya et al., 2010, 2012;

Copyright (C) 2017 The Authors. Published by Aleksandras Stulginskis University. This is an open-access article distributed under the terms of the Creative Commons Attribution License (CC-BY 4.0), which permits unrestricted use, distribution, and reproduction in any medium, provided the original author and source are credited. 
Leon et al., 2013; Cvejić et al., 2014a, b; Ferfuia and Vannozzi, 2015; Jocic et al., 2015; Regitano Neto et al., 2016; Alberio et al., 2016; Angeloni et al., 2016; Cvejić et al., 2016; Dimitrijević et al., 2016; Hlisnikovský et al., 2017).

Pervenent mutations used widely in oleic type sunflower breeding programs. On the other hand, $O l$ gene detection with molecular markers tightly linked to this Pervenent mutations were also developed and used for determined higher oleic type genotypes but they are mostly genotype dependent and some these markers are used commonly in the sunflower breeding programs (Dehmer and Friedt, 1998; Hongtrakul et al., 1998; Lacombe and Bervillé, 2001; Martínez-Rivas et al., 2001; Pérez-Vich et al., 2002; Varès et al., 2002; Schuppert et al., 2006; Nagarathna et al., 2011; Singchai et al., 2013; Van der Merwe et al., 2013; Ferfuia et al., 2015; Bilgen, 2016; Dimitrijević et al., 2017, Rauf et al., 2017).

National Sunflower Research Project conducting by Trakya Agricultural Research Institute (TARI) in Edirne is primary public breeding program in Turkey. Many oleic type sunflower hybrids and inbred lines have been developed until today in National Sunflower Project with genetically resistant to dominant races of downy mildew and new races of broomrape parasite in Trakya Region which has $60 \%$ of sunflower production in Turkey. The aim of this study is to screen of high oleic acid genotypes belonging to this National project based on TUBITAK (The Scientific and Technological Research Council of Turkey) Project 1003-1140971.

\section{MATERIAL AND METHODS}

The study is covered of screening of around 400 sunflower F2 and F3 generation high oleic acid individuals obtained from crosses between high oleic acid and low oleic acid lines were used in TUBITAK (The Scientific and Technological Research Council of Turkey) Project 1003-1140971.

Oleic acid and other fatty acid contents of sunflower genotypes were measured utilizing from Agilent $6850 \mathrm{Gas}$ Chromatography (GC) in Trakya University Food Engineering Lab with using HT 88 type colon in the study. Samples for GC analysis were pressed and their oil extracted with a hydraulic press. About fourteen or fifteen grams of seeds of sunflower genotypes were pressed to obtain crude sunflower oil then two drops of crude oil (approximately $0.5 \mathrm{ml}$ ) that was used for GC analysis were taken and put into $13 \mathrm{ml}$ bottles. Then $10 \mathrm{ml}$ methanol and 0,5 $\mathrm{ml}(2 \mathrm{moll}) \mathrm{methanol} \mathrm{KOH}$ was added to this bottle.

After adding all liquids, it was well shook in the vortex 2-3 minutes, and then kept at room temperature for an hour. The results were processed by the current software in GC and expressed as the percentage of individual fatty acids in the oil sample. Oleic acid and other three major fatty acid contents are shown as the percentage of the content of the total fatty acids. After this waiting period, $2 \mathrm{ml}$ crude oil samples were taken from over parts of crude oils in the vials for GC analysis then put into $2 \mathrm{ml}$ vials to measure of fatty acid contents in GC. All samples were analyzed with two replications in the study.

Oleic acid was identified by use of a reference mixture of fatty acids methyl esters (FAME) containing the methyl esters of other fatty acids was used to confirm the retention times, as well as to confirm that the peak areas reflected the actual composition of these mixtures. After processing by software and stated as the individual fatty acids percentage in the samples, the obtained data were analyzed statistically with JUMP statistical program.

\section{RESULTS AND DISCUSSION}

Four major fatty acids of sunflower genotypes in the segregation generations as F2 and F3 levels were measured by GC. The percentage of fatty acid contents of genotypes were counted and analyzed statistically. Based on the study results, oleic acid contents of sunflower genotypes were changed between 21.9-91.8\%, linoleic acid contents of them between 1.1-66.5\%, palmitic acid contents of them were between 3.4-8.0\% and stearic acid contents of genotypes were changed between 1.1-9.7\% (Table 1).

Oleic acid contents of genotypes were measured mostly over $75 \%$ as called higher oleic acid types as expected so it refers to efficient selection for higher oleic types in the project. Furthermore, other genotypes existed commonly in mid oleic type group (Figure 1). On the other hand, there is a diverse relationship between oleic and linoleic acid contents. Therefore, linoleic acid contents of sunflower genotypes were observed under $10 \%$ linoleic contents as requested in the study (Figure 2).

Table 1. Fatty acid distributions of genetic materials (\%).

\begin{tabular}{lcccccccc}
\hline Fatty Acids & & Maximum & 75\% Quartile & Median & 25\% Quartile & Minimum & Mean & Standard Deviation \\
\hline Oleic Acid & 389 & 91.8 & 89.0 & 84.6 & 56.5 & 21.9 & 71.7 & 20.7 \\
Linoleic Acid & 389 & 66.5 & 33.7 & 3.7 & 2.2 & 0.0 & 18.6 & 20.0 \\
Palmitic Acid & 362 & 8.0 & 4.8 & 4.5 & 4.1 & 3.4 & 4.6 & 0.7 \\
Stearic Acid & 362 & 9.7 & 3.6 & 2.9 & 2.2 & 1.1 & 3.1 & 1.2 \\
\hline
\end{tabular}

The palmitic and stearic acid contents of sunflower genotypes were observed less than 8-9\% of fatty acid contents as expected (Graph 2 and 3). While stearic acid contents of genotypes were accumulated around 4-5\%, stearic acid contents of sunflower genotypes were observed around $1-4 \%$. Of course, lower contents of these two saturated fatty acids in sunflower genotypes is the requested goal in the study. 


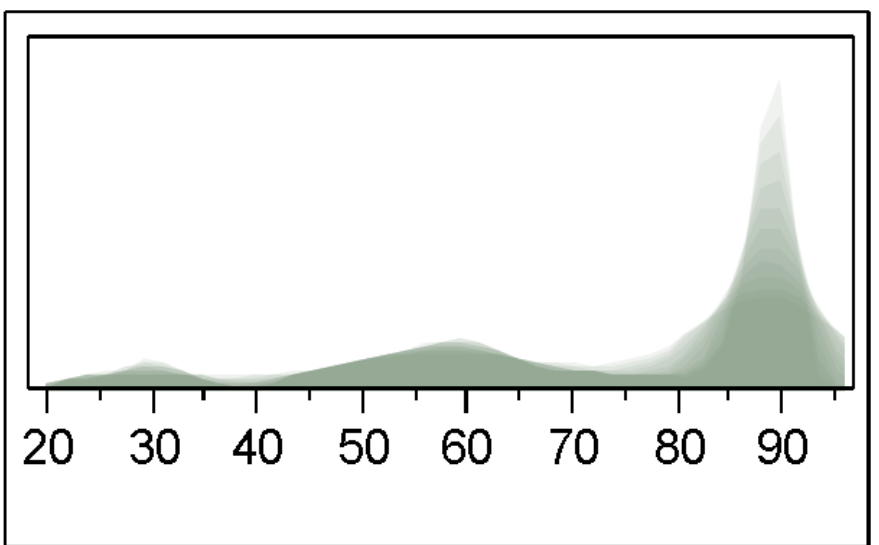

Figure 1. Oleic acid contents of genetic materials (\%)

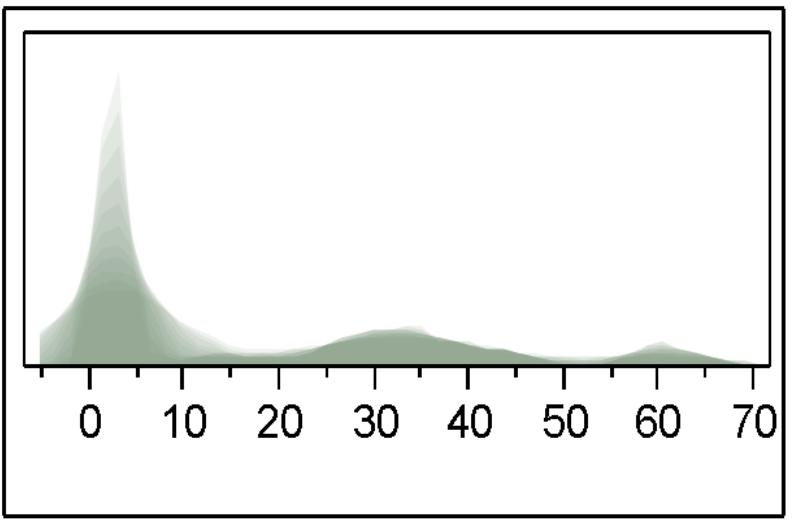

Figure 2. Linoleic acid contents of genetic materials (\%)

The research results mean that breeding efforts for high oleic selection in the sunflower breeding was successful in the project. Especially the developed of over $80-90 \%$ high oleic acid content of sunflower genotypes is final goals of the study. The study results exhibited similarities with other studies on improving oleic contents of sunflower genotypes. Furthermore, the developing of lower saturated fatty acids such as palmitic and stearic acids showed that the performed a successful selection over improving oil quality of sunflower genotypes in the study.

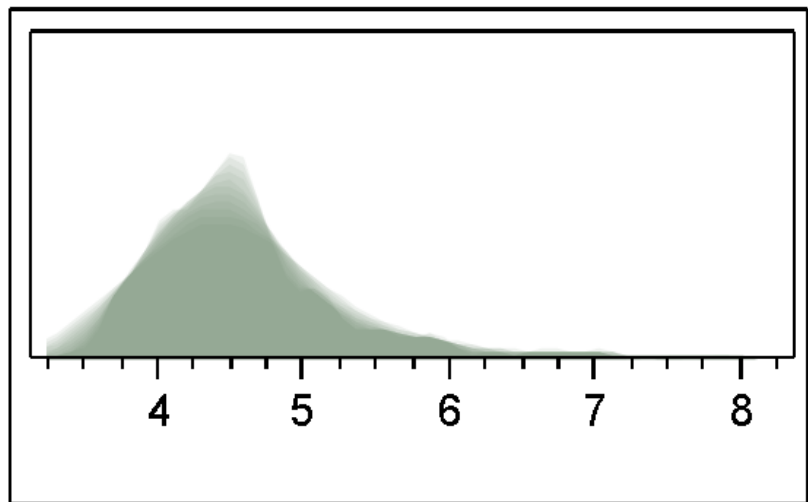

Figure 3. Palmitic acid contents of genetic materials (\%)

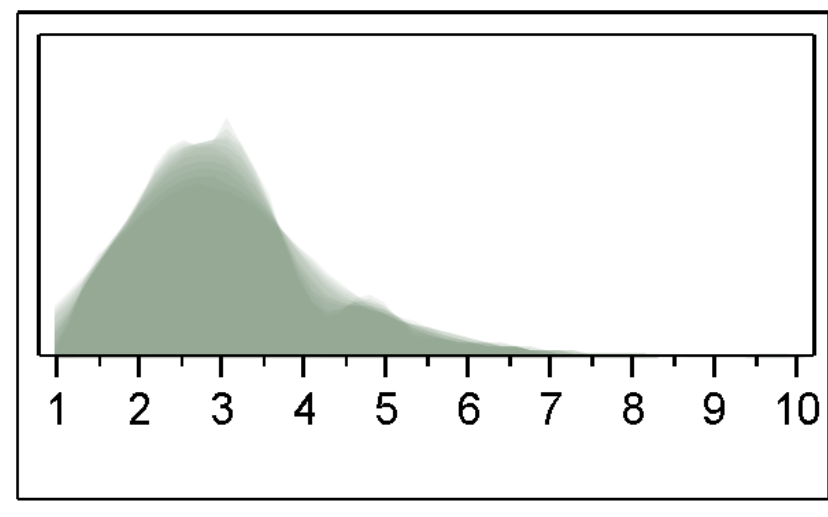

Figure 4. Stearic acid contents of genetic materials $(\%)$

\section{CONCLUSIONS}

The higher oleic type sunflower genotypes were determined via GC analysis in the study and they were mostly found as higher oleic contents over $80 \%$ as expected. These ones were selected for further generations in National Sunflower Breeding Program based on the study results.

\section{ACKNOWLEDGEMENT}

This study was supported by the Scientific and Technological. Research Council of Turkey (TUBITAK) under the Project 1003 1140971 .

\section{REFERENCES}

1. Andrich, G., Balzini, S., Zinnai, A., Fiorentini, R., Baroncelli, S., Pugliesi, C., 1992. The oleic/ linoleic ratio in achenes coming from sunflower lines treated with hard X-rays. In: Proc. 13th International Sunflower Conference, Pisa, Italy, pp. 1544-1549.

2. Alberio C., Izquierdo N. G., Galella, T., Zuil, S., Reid, R., Zambelli, A., Aguirrezábal, L. A. 2016. A new sunflower high oleic mutation confers stable oil grain fatty acid composition across environments. European Journal of Agronomy, Vol. 73, pp. 25-33. https://doi.org/10.1016/i.eja.2015.10.003

3. Angeloni, P., Echarte, M. M., Irujo, G. P., Izquierdo N, Aguirrezábal L. 2016. Fatty acid composition of high oleic sunflower hybrids in a changing environment. Field Crops Research, Vol. 202, pp. 146-157. https://doi.org/10.1016/j.fcr.2016.04.005

4. Baydar H, Erbaş S. 2005. Influence of Seed Development and Seed Position on Oil, Fatty Acids and Total Tocopherol Contents in Sunflower (Helianthus annuus L.) Turkish Journal of Agriculture and Forestry, Vol. 29, pp. 179-186.

5. Bervillé, A., Lacombe, S., Veillet, S., Granier, C., Leger, S., Jouve, P. 2009. Method of selecting sunflower genotypes with high oleic acid content in seed oil. United States patent application, US 11/587,956.

6. Bilgen, B.B. 2016. Characterization of sunflower inbred lines with high oleic acid content by DNA markers. In Kaya, Y. and Hasancebi, S. (eds) Proceedings of the $19^{\text {th }}$ International Sunflower Conference. ISA, Edirne, pp. 662-668. 
7. Cvejić, S., Jocić. S., Dimitrijević, A., Imerovski, I., Miladinović, D., Jocković. M., Miklič, V. 2016. An EMS mutation altering oil quality in sunflower inbred line. Proceedings of the $19^{\text {th }}$ International Sunflower Conference. ISA, Edirne, 422-430.

8. Cvejić, S., Jocić, S., Miladinović, D., Jocković, M., Imerovski, I., Sakač, Z. Miklič, V. 2014a. Development and utilization of sunflower genotypes with altered oil quality. Journal of Processing and Energy in Agriculture, 18: 191-195.

9. Cvejić, S., Miladinović, D., Jocić, S. 2014b. Mutation breeding for changed oil quality in sunflower. In Tomlekova NB, Kozgar MI, Wani MR (eds) Mutagenesis: exploring genetic diversity of crops, pp. 77-96. https://doi.org/10.3920/978-90-8686-796-7_4

10. Dehmer, K.J. Friedt, W. 1998. Development of molecular markers for high oleic acid content in sunflower (Helianthus annuus L.). Industrial Crops and Products, Vol. 7, pp. 311-315. https://doi.org/10.1016/S0926-6690(97)00063-0

11. Demurin, Y. Škorić. D. 1996. Unstable expression of $O l$ gene for high oleic acid content in sunflower seeds. Proceedings of the $14^{\text {th }}$ International Sunflower Conference, ISA, Beijing / Shenyang, pp. 12-20.

12. Demurin, Y. A., Škorić, D., Verešbaranji, I., Jocić, S. 2000. Inheritance of increased oleic acid content in sunflower seed oil. Helia, 23: 87-92.

13. Demurin, Y. Borisenko, O. 2011. Genetic collection of oleic acid content in sunflower seed oil. Helia, Vol. 34, Iss. 55, pp. 69-74. https://doi.org/10.2298/HEL1155069D

14. Dimitrijević, A., Imerovski, I., Miladinović, D., Jocković, M., Cvejić, S., Jocić, S., Zeremski, T., Sakač, Z. 2016. Screening of the presence of Ol gene in NS sunflower collection. $19^{\text {th }}$ International Sunflower Conference. Edirne. pp. 661-667.

15. Dimitrijević, A., Imerovski, I., Miladinović, D., Cvejić, S., Jocić, S., Zeremski, T., Sakač, Z. 2017. Oleic acid variation and markerassisted detection of Pervenets mutation in high- and low-oleic sunflower cross. Crop Breeding and Applied Biotechnology, Vol. 17, pp. 229-235. https://doi.org/10.1590/1984-70332017v17n3a36

16. Evci, G., Kutni, R., Kaya, Y., Pálvölgyi, L., Tar, M., Paricsi, S., Pekcan, V., Gucer, T., Yilmaz, I. M. 2009. Yield performances of oleic type sunflower hybrids in Turkey and Hungary. International Scientific Conference "Good Practices for Sustainable Agricultural Production". pp. 185-193. 12-14 November. Sofia, Bulgaria

17. Ferfuia, C., Vannozzi, G.P. 2015. Maternal effect on seed fatty acid composition in a reciprocal cross of high oleic sunflower (Helianthus annuus L.). Euphytica, Vol. 205, pp. 325-336. https://doi.org/10.1007/s10681-015-1378-3

18. Ferfuia, C., Turi, M. Vannozzi, G.P. 2015. Variability of seed fatty acid composition to growing degree-days in high oleic acid sunflower genotypes. Helia, Vol. 38, pp. 61-78. https://doi.org/10.1515/helia-2014-0022

19. Fernández, H., Baldini, M., Olivieri, A. M. 1999. Inheritance of high oleic acid content in sunflower oil. Journal of Plant Breeding and Genetics, Vol. 53, pp. 99-103. https://doi.org/10.1007/978-0-387-77594-4_6

20. Fernandez-Martinez, J. M., Perez-Vich, B. Velasco, L. 2009. Sunflower. In: Oil Crops, Handbook of Plant Breeding, V.4, Vollmann, J. and Rajcan, I. (Eds.), Springer, 155-232.

21. Fick, G.N. 1984. Inheritance of high oleic acid in the seed oil of sunflower. $6^{\text {th }}$ Sunflower Research Workshop. Bismarck, 9.

22. Hlisnikovský, L., Kunzová, E., Hejcman, M., Škarpa, P., Zukalová, H. Menšík, L. 2017. Oleic acid variation and marker-assisted detection of Pervenets mutation in high- and low-oleic sunflower cross. Crop Breeding \& Applied Biotechnology, Vol. 17, pp. 229-235.

23. Hongtrakul, V., Slabaugh, M.B. Knapp, S. J. 1998. A seed specific D12 oleate desaturase gene is duplicated, rearranged, and weakly expressed in high oleic acid sunflower lines. Crop Science, Vol. 38: pp. $1245-1249$. https://doi.org/10.2135/cropsci1998.0011183X003800050022x

24. Izquierdo, N. G., Aguirrezábal, L.N., Andrade, F.H., Cantarero, M.G. 2006. Modeling Response of Fatty Acid Composition to Temperature in a Traditional Sunflower Hybrid. Agronomy Journal, Vol. 98, pp. $451-461$. https://doi.org/10.2134/agronj2005.0083

25. Izquierdo, N. G., Aguirrezábal, L.A. 2008. Genetic variability in the response of fatty acid composition to minimum night temperature during grain filling in sunflower. Field Crops Research, Vol. 106, pp. 116-25. https://doi.org/10.1016/j.fcr.2007.10.016

26. Jocic, S., D. Miladinovic, Kaya, Y. 2015. Breeding and Genetics of Sunflower. N. Dunford, E. M. Force (Ed) Sunflower: Chemistry, Production, Processing, and Utilization. AOCS (American Oil Chemistry Society), pp. 1-26.

27. Joksimović, J., Atlagić, J., Marinković, R. Jovanović, D. 2006. Genetic control of oleic and linoleic acid contents in sunflower. Helia, Vol. 29, pp. 33-40. https://doi.org/10.2298/HEL0644033J

28. Kaya, Y., Kaya, V., Şahin, I., Üstün Kaya, M., Evci, G., Çıtak, N. 2008. The Future Potential of Oleic Type Sunflower in Turkey. Proceeding of $17^{\text {th }}$ International Sunflower Conference, Vol. 2, pp. 791-796. Cordoba, Spain. June 8-12.

29. Kaya, Y., Evci, G., Pekcan, V., Gucer, T., Yilmaz, I. M., Şahin, I., Citak, N. Ay, O. 2010. Fatty Acid Changes and its Relationships in Sunflower Cultivars. Proceedings of the 12th International Sunflower Conference. March 1-3. Antalya, Turkey. 90.

30. Kaya, Y., Jocic, S. Miladinovic, D. 2012. Sunflower. S.K. Gupta. (Ed) Technological Innovations in Major World Oil Crops, Vol. 1, pp. 85-129.

31. Kaya, Y. 2016. Oleic Type Sunflower Breeding: Current Situation and Future Directions. Proceedings of the 3rd edition of the High Oleic Oils Congress, pp. 156-207. 6-8 September, Toulouse, France.

32. Kaya, Y., I. Balalic, V. Miklic. 2015. Eastern Europe Perspectives on Sunflower Production and Processing. N. Dunford, E. M. Force (Ed) Sunflower: Chemistry, Production, Processing, and Utilization. AOCS (American Oil Chemistry Society, pp. 575-638.

33. Lacombe, S., Bervillé, A. 2001. A dominant mutation for high oleic acid content in sunflower (Helianthus annuus L.) seed oil is genetically linked to a single oleate-desaturase RFLP locus. Molecular Breeding, Vol. 8, pp. 129-137.

34. Lacombe, S., Leger, S., Kaan, F., Bervillé, A. Sas, M. 2002. Genetic, molecular and expression features of the Pervenets mutant leading to high oleic acid content of seed oil in sunflower. Oléagineux, Corps gras, Lipides, Vol. 9, pp. 17-23. $\underline{\text { https://doi.org/10.1051/ocl.2002.0017 }}$ 


\section{Proceedings of the $8^{\text {th }}$ International Scientific Conference Rural Development 2017}

35. Lacombe, S., Guillot, H., Kaan, F., Millet, C., Bervillé, A. 2000. Genetic and molecular characterization of the high oleic content of sunflower oil in Pervenets. Proceedings of the 15th International Sunflower Conference. ISA, Toulouse, pp. 12-15. https://doi.org/10.2298/HEL0440041L

36. Lacombe, S., Leger, S., Kaan, F., Bervillé, A. Sas, M. 2002. Genetic, molecular and expression features of the Pervenets mutant leading to high oleic acid content of seed oil in sunflower. Oléagineux, Corps gras, Lipides, Vol. 9, pp. 17-23.

37. Lacombe, S., Kaan F., Griveau, Y. Bervillé, A. 2004. The pervenets high oleic mutation: methodological studies. Helia, Vol. 27, pp 41-54.

38. Lacombe, S., Souyris, I., Bervillé, A.J. 2009. An insertion of oleate desaturase homologous sequence silences via siRNA the functional gene leading to high oleic acid content in sunflower seed oil. Molec. Genetics \& Genomics, Vol. 281, pp. 43-54. https://doi.org/10.1007/s00438-008-0391-9

39. Leon, A. J., Zambelli, A. D., Reid, R.J., Morata, M.M., Kaspar, M., Martinez-Force, E., Garcés, R., Salas, J.J., Venegas-Caleron, M. 2013. Isolated mutated nucleotide sequences that encode a modified oleate destaurase sunflower protein, modified protein, methods and uses. WIPO Patent WO/2013/004280, Jan 10.

40. Martínez-Rivas, J.M., Sperling, P., Luehs, W., Heinz, E. 2001. Spatial and temporal regulation of three different microsomal oleate desaturase genes (FAD2) from normal-type and high oleic varieties of sunflower (Helianthus annuus L.). Molecular Breeding, Vol. 8, pp. 159-168. https://doi.org/10.1023/A:1013324329322

41. Nagarathna, T.K., Shadakshari, Y.G., Ramanappa, T.M. 2011. Molecular analysis of sunflower (Helianthus annuus L.) genotypes for high oleic acid using microsatellite markers. Helia, Vol. 34, pp. 63-68. https://doi.org/10.2298/HEL1155063N

42. Osorio, J., Fernández-Martinez, J.M., Mancha, M. Garces, R. 1995. Mutant sunflower with high concentration in saturated fatty acid in the oil. Crop Science, 35: 739-742. https://doi.org/10.2135/cropsci1995.0011183X003500030016x

43. Pacureanu-Joita M., Vranceanu, A.V., Stanciu, D., Raranciuc, S. 1999. High oleic acid content in sunflower genotypes in relation with resistance to diseases. Romanian Agricultural Research, Vol. 11-12, pp. 21-27.

44. Pacureanu-Joita, M., Stanciu, D., Petcu, E., Raranciuc, S., Sorega, I. 2005. Sunflower genotypes with high oleic acid content. Romanian Agricultural Research, Vol. 22, pp. 23-26.

45. Pérez-Vich, B., Fernández-Martínez, J. M., Grondona, M., Knapp, S. J. Berry, S.T. 2002. Stearoyl-ACP and oleoyl-PC desaturase genes cosegregate with quantitative trait loci underlying high stearic and high oleic acid mutant phenotypes in sunflower. Theoretical and Applied Genetics, Vol. 104, pp. 338-349. https://doi.org/10.1007/s001220100712

46. Rauf, S., Jamil, N., Ali Tariq, S., Khan, M., Kausar, M., Kaya, Y. 2017. Progress in modification of sunflower oil to expand its industrial value. Journal of the Science of Food and Agriculture. https://doi.org/10.1002/jsfa.8214

47. Regitano Neto, A, Miguel, A., Mourad, A.L., Henriques, E.A. Alves, R.M.V. 2016. Environmental effect on sunflower oil quality. Crop Breeding and Applied Biotechnology, Vol. 16, pp. 197-204. https://doi.org/10.1590/1984-70332016v16n3a30

48. Schuppert, G.F., Tang, S., Slabaugh, M. B. Knapp, S. J. 2006. The sunflower high-oleic mutant Ol carries variable tandem repeats of FAD2-1, a seed-specific oleoyl-phosphatidyl choline desaturase. Molecular Breeding, Vol. 17, pp. $241-256$. https://doi.org/10.1007/s11032-005-5680-y

49. Singchai, A., Muangsan N., Machikowa, T. 2013. Evaluation of SSR markers associated with high oleic acid in sunflower. International Journal of Biological, Food, Veterinary and Agricultural Engineering, Vol. 7, pp. 631-634.

50. Skorić, D., Jocić, S., Lecic, N., Sakac, Z. 2007. Development of sunflower hybrids different oil quality. Helia, Vol. 30, pp. 205212. https://doi.org/10.2298/HEL0747205S

51. Soldatov, K.I. 1976. Chemical mutagenesis in sunflower breeding. In Proceedings of the $7^{\text {th }}$ International Sunflower Conference. ISA, Krasnodar, pp. 352-357.

52. Urie, A. L. 1984. Inheritance of very high oleic acid content in sunflower. In Proceedings of the $6^{\text {th }}$ Sunflower Research Workshop. National Sunflower Association, Bismarck, pp. 8-9.

53. Van der Merwe, R., Labuschagne, M.T., Herselman, L., Hugo, A. 2013. Stability of seed oil quality traits in high and mid-oleic acid sunflower hybrids. Euphytica, Vol. 193, pp. 157-68. https://doi.org/10.1007/s10681-013-0888-0

54. Vannozzi, G.P. 2006. The perspectives of use of high oleic sunflower for oleochemistry and energy raws. Helia, 29 : 1-24. https://doi.org/10.2298/HEL0644001V

55. Varès, D., Lacombe, S., Griveau, Y., Bervillé, A., Kaan, F. 2002. Inheritance of oleic acid content of $F_{1}$ seed in a complete diallel cross between seven sunflower lines. Helia, 25: 105-12. https://doi.org/10.2298/HEL0236105V

56. Velasco, L., Pérez-Vich, B, Fernández-Martínez, J.M. 2008. A new sunflower mutant with increased levels of palmitic acid in seed oil. Helia, Vol. 31, pp. 55-60. 